\title{
The Effect of Intangible Assets on Financial Performance, Financial Policies, and Market Value of Technology Firms: A Global Comparative Analysis
}

\author{
Muhammad Junaid Qureshi (Corresponding author) \\ Research Scholar \\ Karachi University Business School, University of Karachi, Pakistan \\ E-mail: junaidqureshi94@gmail.com \\ Dr. Danish Ahmed Siddiqui \\ Associate Professor \\ Karachi University Business School, University of Karachi, Pakistan \\ E-mail: daanish79@ hotmail.com
}

Received: March 1, 2020 Accepted: April 15, $2020 \quad$ Published: June 1, 2020

doi:10.5296/ajfa.v12i1.16655 URL: https://doi.org/10.5296/ajfa.v12i1.16655

\begin{abstract}
Purpose: The purpose of this study is to examine the degree to which intangible assets effect financial performance, financial policies and market value of the technology firm.

Design/methodology/approach- Structural equation modeling analysis was used to ascertain the relationship among intangible assets, firm performance, firm policies, and market value in the year 2015 to 2018 of 80 companies according to the market capitalization of their respective countries in the technology sector globally. The measures used in this study profitability efficiency, capital structure, dividend policy and market value that is calculated through the proxies ROA, ROE, ROIC, ATO, Net Profit Margin, debt to equity ratio, dividend payout ratio, price-earnings ratio, price to sales and price to book value.
\end{abstract}

Finding- The results from Multi group Analysis (MGA) revealed that there are differences ( $p$ $<.05)$ in the significance of the impact of Assets on the criterion variable between a few countries for instance Asset's impact on ROIC is significantly different between Russia \& China and USA. 


\section{Macrothink}

Practical implications- Owners and managers of technological sector global companies must recognize the importance of both the physical capital and the intangible resources to the best interest of the companies

Originality/value- This is the first paper to examine the impact of intangible assets on firm performance, policies and value through cross country analysis in the technological sector.

Keywords: Firm Performance, Firm Policies, Firm value, Intangible assets, SEM analysis, Technological Industry 


\section{Introduction}

\subsection{Background of the Study}

Researchers and practitioners have reached a consensus that intangible assets play a vital role in the success and survival of firms in today's economy Satt, Harit \& Youssef, Chetioui. (2017). In recent decades, the focus has shifted from the traditional financial statements that focus on tangible assets into intangible assets like innovation, knowledge, intellectual property, and goodwill.

Rapidly changing dynamics of globalization and increasing market competition, companies all around the world confronting several new challenges and opportunities (Bchini, 2015). To be competitive and successful apart from the relative importance of physical sources, companies have to adopt modern strategies and policies regarding market flexibility and development (Hejazi, Ghanbari, \& Alipour, 2016). Moreover, the evolution of the knowledge economy from the industrial economy also puts greater pressure on companies to use soft resources efficiently as human capital and knowledge, which have become major factors of economic growth. In past, companies' success, profitability and value mainly depend on tangible assets like land, infrastructure, and equipment (Nuryaman, 2015) but in current global economy intangible assets contributing approximately $80 \%$ in companies' value through human capital development and knowledge management (Vodák, 2011).

Amortization of 'goodwill' has serious shortcomings, hence, the emergence of IFRS 3, SFAS $141 \mathrm{R}$ and SFAS 142. That is, goodwill and other intangibles are made up of unrelated components: the new goodwill comprising of reputation (Iwu-Egwuonwu, 2011), human capital and organizational capital, have indefinite life albeit highly volatile and perishable. Conversely, there are definite lives for patents, copyrights, licenses, trademarks and royalties. To order to assess how intangibles increase the value and profitability of a business, these components should be evaluated separately and their effects recorded. (Henning, Lewis and Shaw, 2000). Regrettably, only those components which have definite valid lives can be calculated quantitatively. Those components with infinite lives which have a major positive impact on firm value / growth are highly qualitative and are not easily quantitatively calculated.

In the modern business era, intangible assets are vital strategic resources. They are extremely important in creating corporate value (Gamayuni, 2015) and improving company performance. Researches indicated that intangible assets abound throughout the business world, touching nearly all aspects of a company, from product development to human capital, and staff functions such as legal, accounting, finance, and line operations such as research and development, marketing, and general management.

In a macro scenario, investments in intangible assets have grown rapidly among companies in the United States, Japan, and Europe. Such growth has been amplified by intensified global competition, use of information and communication technologies, adoption of new business models, and prevalence of the services sector. The report of the Organization for Economic Cooperation and Development (OECD, 2011) cited that such investments have a significant 
impact on productivity. It also indicated that in some cases the investments match or exceed those in the traditional capital such as machinery, equipment, and buildings.

(Lim Macias et al 2018) found a strong relationship between identifiable intangible assets \& financial leverage. Overall identifiable intangible assets support debt financing in firm that lack abundant tangible assets. While the dataset provides the fair value estimates of intangible assets for only a small subset of firms. Harrit Satt et al (2017) studied the effect of goodwill on firm performance found that a high level of goodwill has a positive impact on firm's performance, however, the research is conducted in the MENA region. Rufo Mendoza (2017) studied the importance of intangible assets in improving financial performance, creating value \& maintain competitiveness, it was conducted in the Philippines Stock exchange.

The Effect of Intangible assets on financial policy, financial performance \& firm value covered rarely in previous literature, only one paper available in Gamayuni (2015) but that is also in the context of Indonesia in the manufacturing industry. In short, studies undertaken are mostly limited to country or region-specific studies. In our opinion, intangible assets are not related to region but to sectors, different sectors have their own peculiar requirement. We for the first time covered the whole sector globally. We choose the technology sector, as it as a high degree of intangibles as compared to other, and have a more pronounced effect on performance. Moreover, comparative analysis of factors affected by intangible assets could also highlight the country- specific underlying trend in tech sector, and where it's significant enough to overshadow industry- specific characteristics.

Researchers have long recognized that intangible assets can be critically important to firm value and affect firms' financial policies. For example, the patents of Apple and Pfizer, the brands of Coke and Amazon, the unique supply chain of Walmart, and the highly efficient business process of Southwest Airlines have bolstered the competitive advantages and corporate values of these firms in the knowledge economy (Lev and $\mathrm{Gu}$ 2016). However, it has been difficult to document intangibles' effects on firms' financial policies because the conservative accounting practice does not recognize the most internally-generated intangible assets on the balance sheet. For example, firm's expense advertising as well as research and development $(R \& D)$ expenditures, except for certain software development costs. In contrast, accounting capitalizes externally acquired intangible assets. Peters and Taylor (2017) estimate that firms purchase only $19 \%$ of their intangible assets externally. 1 The Economist (2014) reports that "In 2005 Procter \& Gamble, a consumer-goods company, paid $\$ 57$ billion for the Gillette razor company. The brand alone, $\mathrm{P} \& \mathrm{G}$ reckoned, was worth $\$ 24$ billion." For these intangible assets, researchers typically can observe neither book nor market or fair values.

In this information era, intangible assets dominate the environment compared to during the industrial era that was dominated by tangible assets. Zhang (2017) found that the inferred intangibles have predictive power for stock returns, which might be because of mean-reverting misevaluation by the stock market; and the way the inferred intangibles predict stock returns is consistent with the three-factor model of Fama and French (1992). These changes have led the role of intangibles to increase to provide a more informative and reflective business performance intended for the investors in the decision-making process 
which the traditional accounting standards cannot fulfill anymore (Wilson, et.al. 2014; Yu-Chi and Lin, 2018).

\subsection{Problem Statement}

Some types of intangible assets or intellectual property are not mentioned in any other financial statements, because monetary value is difficult to calculate or quantify. Intellectual capital is the community of information assets assigned to an organization, which contributes most significantly to this organization's improved competitive position, identified by adding value to key stakeholders (Marr and Schiuma, 2001). According to Sveiby (1998), The unseen intangible component of the balance sheet can be described as a family of three, individual competence, internal structure and external structure". Meanwhile, Leif Edvinsson, as quoted by equates intellectual capital as amount of human capital and structural capital (eg, relationships with consumers, network management and information technology). Choong (2008) calculated excess ROA intellectual capital as composed of intangible individual, company and institutional properties. Intellectual capital can thus be characterized as the amount of what is generated by the organization's three main elements (human capital, structural capital, and customer capital) related to information and technology which can provide a competitive form of organization with more value for the client. Roos et al. (1997) Revealed that these companies 'market value is several times their net asset value which is the value of their tangible value. The difference between the two values is the "secret value" of the product, which can be expressed as a market value percentage. On the basis of these statements it can be inferred that intellectual capital is the key factors which can increase the market value and therefore the profitability of a business

R\&D investment occupies an significant role in terms of intangible asset efficiency, value, and risk. R\&D investments also influence the market value of the company which is expressed in sales and return (Sougiannis, 1994). Under IAS 38, spending on research and development may be counted as investment or assets. The option will have an effect on financial results.

Intangible assets have 5 unique characteristics according to Holmstrom (1989): 1. Long-run, 2. Unable to predict the outcome, 3. Strong bankruptcy risk, n. 4. Intense labour, 5. Local. Such specific features impact financial policies within the company. Investment in intangible assets influences the budget and dividend policy of the company's debt. Theory of Agencies (Jensen and Meckling, 1976) argues that Company expenses are dictated by monetary policy. The expense of the business is projected to be higher in businesses with concentrated intangible assets, based on the particular characteristics of intangible assets. Intangible assets will raise the cost of the agency to shareholders (due to more details and secret action), as well as the cost of the debtor agency (asset replacement and underinvestment problem). Thus, investment in intangible assets will affect the company's financial policy.

Previous studies have been conducted to prove the influence of company's financial performance to stock return. It has been shown that the ratios extracted from the financial statements have a strong relationship with the stock market metrics, which indicates that the financial statements are also useful to investors in decision making and may clarify the value 
of the stock market. Several other studies found that the structure of financial risks and smoothing earnings has worked at firm value. Investment opportunity set and the leverage effect on firm value. These results are consistent with Modigliani and Miller's opinion that the enterprise value is determined by the earnings power of the company's assets. So ROA is one of the factors that affect firm value. The same results on the research by Carlson and Bathala (1997).

According to The Wall Street Journal, the rate of intangible investment as a percentage of private-sector gross domestic product (GDP) overtook tangible investment in the mid-1990s. Intangible assets in term of improvement firm performance, impact on firm value $\&$ policies covered rarely in previous literates, some paper cover some aspects of intangible assets (Rindu Rika Gamayun, 2015); (Vladimir Dženopoljac Stevo Janoševic Nick Bontis 2016). But that is also in the context of certain countries not cross-sectional for the majority of countries. Some other investigated in majority about intangible assets, as studied in different papers (Melsa et al, 2015); (Onipe A. Yahya et al,2015); (lihard Stevanus et al 2017); (Rufo R Mendoza 2017);(Zeb, S. \& Rashid A 2016); (Lim S.C Macias et al 2018). Previously studies were conducting examining intangible assets of a particular country or market in different sectors.

\subsection{Research Objective}

We have studied sectorial analysis of the manufacturing \& services sector globally among 14 countries in technological sectors from 2015 to 2018 because of the most recent data availability of company's annual reports, where most companies spend a large amount of investment in intangible assets \& also try to compare different groups with each other. This study is particularly important because intangible assets ratio in total assets has been significantly increased in many countries. We tend to find the impact of intangible assets on financial performance, firm policy \& firm value in the global technology sector. The current paper covers how intangibles impact dependent variables $\&$ how these vary among countries.

\subsection{Outline of the Study}

We review in all previous papers \& find the gap that the intangible plays a very prominent role to drive the firm performance $\&$ impact on the firm value $\&$ policies. We design our methodology to test the validity of intangible assets globally by sectorial analysis of each country \& its influence on the financial performance of companies. We collect data on financial indicators of 14 countries from financial statement of 80 companies in technological sector. We rely on the financial statement data source because of authenticity of data. We obtain data for 14 countries of ROA, ROE, ROIC, ATO, Operating Profit, Intangible assets, Debt to Equity, Dividend Payout Ratio, Price to Earnings Ratio, Price to Book Value \& Price to Sales Ratio. We make Intangible assets as independent variable \& rest of all as dependent variables. We take four years from 2015 to 2018 and run different test to support our results. We run test on smart pls 3 and find correlation and regression analysis. Based on test result we interpret and conclude our research. 


\section{Literature Review}

Haji and Ghazali (2018) suggest the better investment in intangible resources to improve the financial performance of companies. Investment in human capital and technology has the perspective to improve the profitability and the lack of investment can results in weaker firm performance.

Ozkan, Cakan, and Kayacan (2017) examine the association among investment in intangible assets and banking profitability in the short and long run by using panel data. Their results indicate that the intangible assets improve the banking performance in the long run

Nijun Zhang (2017) researched on the effect of intangible assets on firms' economic performance in listed telecommunication firms in China. Intangible assets ratio (intangible assets divided by total assets) is used as an independent variable whereas the return on assets (ROA) as the dependent variable. Assets are future economic benefits controlled by using the entity as an end result of past transactions or other previous events. Intangible assets are the companies' aggressive advantage and challenging to imitate. In the Chinese accounting standards, intangible belongings include patents, copyright, franchise, and land-use right. There is an assumption that if in China, intangible belongings owned with the aid of businesses can promote corporation's performance higher than tangible assets, the market structure is aggressive and mature. Hence a positive and significant correlation was found between intangible assets and the firm's profitability.

Vladimir Dženopoljac, Stevo Janoševic \& Nick Bontis DeGroote (2016) investigated the influence of intellectual capital (IC) on financial performance in information communication technology (ICT) industry of Serbia. Financial performance is measured by the following ratios; return on equity, return on assets, return on invested capital, profitability, and asset turnover. Knowledge administration and IC are regarded among the youngest administration disciplines to have received acceptance in the scientific community. The results of this study indicate that there are no significant differences found in economic performance among different ICT subsectors.

Jasenka Bubic \& Toni Susak (2015) study the relationship between investment in intangible assets represented by intangible assets to total assets ratio and financial performance of companies represented by Return on Assets, Return on Equity, Net Profit Margin, and Gross Profit Margin. Intangible assets are commercial enterprise sources of a company.

Gamayuni (2015) empirically tests the relationship between intangible assets, financial policies, and financial performance on firm value in Indonesia's going-public business. Process analysis was used in 2007-2009 to assess the relationship between intangible assets, financial policies, financial performance, and firm value in Indonesia's going-public company. Interestingly, intangible assets, financial policies, and financial performance have a significant impact on firm value. Important assets have no significant influence on financial policies but have had a positive and significant impact on financial performance (ROA) and firm value. Debt policies and financial performance (ROA) have had a strong and important impact on firm price. Limitation of financial statements in measuring and disclosing 


\section{Macrothink}

intangible assets is the cause of a significant difference between equity of book value and equity of market value.

Intangible assets are being transformed into an unrivaled resource for business wealth creation. While tangible assets such as structures, facilities and equipment continue to be the main elements in the production of goods and services, the relative importance has declined over time as the significance of intangible assets replaces tangible assets (Martins \& Alves, 2010)

\section{Conceptual Framework}

\subsection{Dependent Variables}

The dependent variable in this paper is Profitability, Efficiency, Capital Structure, dividend policy and market value which is measured through the proxies of ROA, ROE, ROIC, ATO, Net Profit margin, Debt to Equity Ratio, Dividend payout ratio, Price Earnings Ratio, Price to Sales Ratio and Price to Book Value. Definitions of the variables mentioned in table 1: 


\section{Table 1. Definitions of variables}

\begin{tabular}{|c|c|c|}
\hline & Variables & Definitions \\
\hline 1 & $\begin{array}{l}\text { Return on Assets } \\
\text { (ROA) }\end{array}$ & $\begin{array}{l}\text { Return on assets (ROA) is an indicator of how profitable a company is relative to its } \\
\text { total assets. ROA gives a manager, investor, or analyst an idea as to how efficient a } \\
\text { company's management is at using its assets to generate earnings }\end{array}$ \\
\hline 2 & $\begin{array}{l}\text { Return on } \\
\text { Equity (ROE) }\end{array}$ & $\begin{array}{l}\text { Return on equity (ROE) is a measure of financial performance calculated by dividing } \\
\text { net income by shareholders' equity. Because shareholders' equity is equal to a } \\
\text { company's assets minus its debt, ROE could be thought of as the return on net assets. }\end{array}$ \\
\hline 3 & $\begin{array}{l}\text { Return on } \\
\text { Invested Capital } \\
\text { (ROIC) }\end{array}$ & $\begin{array}{l}\text { Return on Invested Capital and is a profitability or performance ratio that aims to } \\
\text { measure the percentage return that investors in a company are earning from their } \\
\text { invested capital. It also represents the residual value of assets minus liabilities. }\end{array}$ \\
\hline 4 & $\begin{array}{l}\text { Assets Turnover } \\
\text { (ATO) }\end{array}$ & $\begin{array}{l}\text { Asset turnover (ATO) or asset turns is a financial ratio that measures the efficiency of a } \\
\text { company's use of its assets in generating sales revenue or sales income to the company }\end{array}$ \\
\hline 5 & Profitability & $\begin{array}{l}\text { Profitability ratios consist of a group of metrics that assess a company's ability to } \\
\text { generate revenue relative to its revenue, operating costs, balance sheet assets, and } \\
\text { shareholders' equity. }\end{array}$ \\
\hline 6 & $\begin{array}{l}\text { Debt to Equity } \\
\text { Ratio }\end{array}$ & $\begin{array}{l}\text { The debt-to-equity (D/E) ratio is calculated by dividing a company's total liabilities by } \\
\text { its shareholder equity. These numbers are available on the balance sheet of a company's } \\
\text { financial statements. The ratio is used to evaluate a company's financial leverage. }\end{array}$ \\
\hline 7 & $\begin{array}{l}\text { Dividend Payout } \\
\text { Ratio }\end{array}$ & $\begin{array}{l}\text { The dividend payout ratio is the ratio of the total amount of dividends paid out to } \\
\text { shareholders relative to the net income of the company. It is the percentage of earnings } \\
\text { paid to shareholders in dividends. }\end{array}$ \\
\hline 8 & $\begin{array}{l}\text { Price Earnings } \\
\text { Ratio }\end{array}$ & $\begin{array}{l}\text { The price to earnings ratio (PE Ratio) is the measure of the share price relative to the } \\
\text { annual net income earned by the firm per share. PE ratio shows current investor } \\
\text { demand for a company share }\end{array}$ \\
\hline 9 & $\begin{array}{l}\text { Price to Sales } \\
\text { Ratio }\end{array}$ & $\begin{array}{l}\text { The price-to-sales ratio (Price/Sales or P/S) is calculated by taking a company's market } \\
\text { capitalization (the number of outstanding shares multiplied by the share price) and } \\
\text { divide it by the company's total sales or revenue over the past } 12 \text { months. }\end{array}$ \\
\hline 10 & $\begin{array}{l}\text { Price to Book } \\
\text { value }\end{array}$ & $\begin{array}{l}\text { The price-to-book, or } \mathrm{P} / \mathrm{B} \text { ratio, is calculated by dividing a company's stock price by its } \\
\text { book value per share, which is defined as its total assets minus any liabilities }\end{array}$ \\
\hline
\end{tabular}




\subsection{Independent Variable}

In this paper data collected for 4 years (2015-2018) from 80 companies selected for intangible assets. Intangible assets are an important indicator and taken as an independent variable in this study.

Intangible assets are non-monetary assets besides physical traits that can be identified. They include of following categories of assets: research and development, patents, concession rights, trademarks, software, permissions for fishing, franchisees, and other rights, goodwill, boost repayments for the buy of intangible asset and different intangible assets.

Capitalized intangible fixed assets and expensed R\&D expenses scaled by total assets represent our explanatory variables whereas market to book value ratio as the dependent variable. Intangible belongings lack bodily substance and do not have a monetary embodiment. The valuation of this form of belongings is tough and uncertain. Intangible property commonly relates to improvements implementation, technological know-how improvement or advertising and marketing activities. The increase in the quantity of company intangible belongings influences the firms' behavior. One of the modern-day tendencies is that intangible belongings emerge as the foremost transferring channel of income shifting and switch pricing manipulation. The function of intangibility is related to a number of issues of valuation of internally generated intangible assets. Those are divided into two groups: identifiable and unidentifiable intangible assets. The valuation of intangible belongings is particularly necessary for the pricing of mergers and acquisitions. Results assert that there is a positive and significant relationship among dependent and independent variables.

\subsection{Development of Research Hypothesis}

According to IAS 38, spending on R\&D can be counted as investment or assets. This option will impact financial performance, but it is difficult to estimate the effect because it raises the information asymmetry between shareholders and managers. Canibano, Garcia-Ayuso, and Sanchez (2000) in Lantz, et al. (2005) show the presence of improved returns due to increased spending on research and development, so hypothesis derived from this literature review.

H1. Intangible asset has a direct positive impact on financial performance of the technology firm

H1a. Intangible assets has significant effect on ROE.

H1b. Intangible assets has significant effect on ROA.

H1c. Intangible assets has significant effect on ROIC.

H1d. Intangible assets has significant effect on Net Profit Margin.

H1e. Intangible assets has significant effect ATO.

The theory of the agency cost (Jensen and Meckling, 1976) suggests that the expense of the agency cost influences monetary policy. Depending on the unique characteristics of 
intangible assets, in organizations with concentrated intangible assets, the expense of the business is projected to be higher. Intangible assets would increase the cost of the business to shareholders (due to more details and secret action), including the cost of the debtor agency (asset substitution and underinvestment problem) so the second testing hypothesis derived from this theory.

H2. Intangible asset has a direct positive impact on financial policy of technology firm

H2a. Intangible assets affect debt policy.

$\mathrm{H} 2 \mathrm{~b}$. Intangible assets affect the dividend policy.

Agrawal and Knoeber (1996) result in a positive and important connection of intangible investment to the market value of the company. And so, in her research, Connolly and Hirschey's (1984) show a positive correlation between intangible spending and firm interest. Erawati and Sudana (2005) suggested the idea that, together with the tangible assets, intangible assets are one category that: (1) assess the company's value and (2) influence the financial performance of the company.

H3. Intangible asset has a direct positive impact on market value of technology firm.

H3a. Intangible assets has significant effect on P/E.

$\mathrm{H} 3 \mathrm{~b}$. Intangible assets has significant effect on P/Book value.

$\mathrm{H} 3 \mathrm{c}$. Intangible assets has significant effect on P/Sales.

By testing the $\mathrm{H} 4$, we can determine that if there is significant differences occur in the sector of the technological firm or not that is (manufacturing \& service) because in some papers such as Miyagawa (2015) investigate and proposed that service sector rely more on intangible assets than manufacturing so we tested this among global technology firms

H4. The contribution of intangible assets to a company's financial performance, financial policies \& market value will not be significantly different among the global technological subsector.

Hypothesis 5 is used to test that if result varies from country to country or not because in most countries this is not reported due to the lack of ability of the accounting standards issued to date. Intangibles are among the fundamental determinant of the value of business enterprises. Currently, most of the intangibles are only revealed indirectly by incremental economic performance (Mortensen, Eustace and Lannoo, 1997).

H5: The contribution of intangible assets to the company's financial performance, financial policy, and market value will not be significantly different among different country's groups.

\subsection{Model Evaluation}

The model developed in this study examines the inter-relationship between intangible assets, financial performance (Profitability, ROA, ATO, ROE, ROIC), financial policy (Debt Policy and Dividend Policy), and firm value (P/E, P/Book Value, and P/Sales). The PLS model is 


\section{MInstitute Macrothink}

shown in Figure 1.

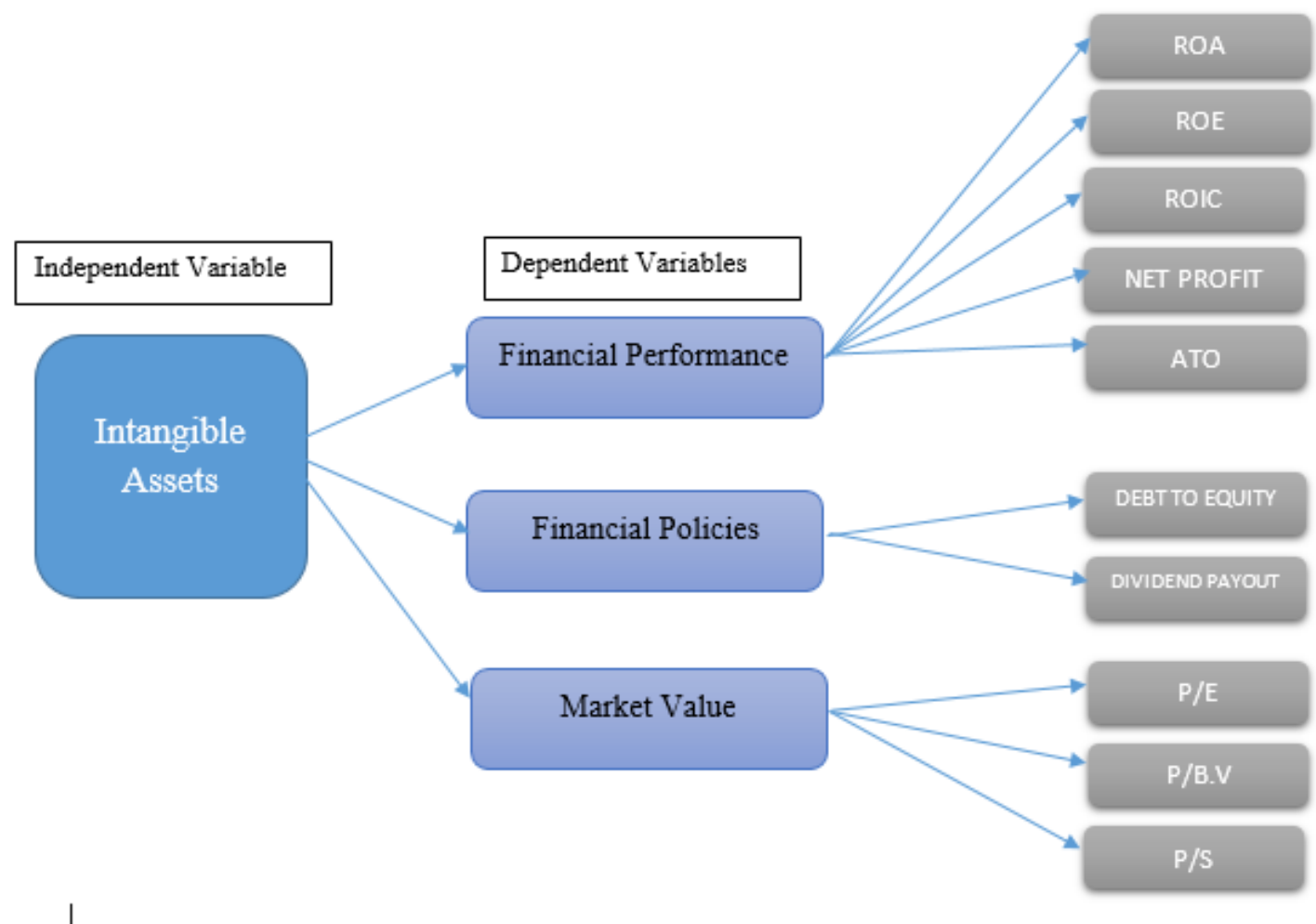

Figure 1. Model of the Study

\section{Methodology}

\subsection{Sample}

The sample of the study included globally technological sector companies of high market capitalization in their respective country. The sample was restricted only to companies that reported financial information about intangible assets in their balance sheet or annual reports for the years 2015-2018 due to availability these years' data on the company's websites. The number of companies included in the sample was 80 companies with respect to its market capitalization in their respective countries that heavily rely on intangible assets. In the technological sector; the total number of observations collected from years understudy was 320 observations.

Table 2. List of Countries with Companies Name \& Sectors

\begin{tabular}{|c|c|c|c|}
\hline S \# & Country & Companies Name & Sector \\
\hline \multirow{2}{*}{1} & \multirow{2}{*}{ Brazil } & Adobe Inc. & Services \\
\cline { 3 - 4 } & & Broadcom Inc. & Manufacturing \\
\hline
\end{tabular}




\begin{tabular}{|c|c|c|c|}
\hline & & Sinqia S.A & Services \\
\hline \multirow{5}{*}{2} & \multirow{5}{*}{ China } & Hangzou & Manufacturing \\
\hline & & Midea Group & Manufacturing \\
\hline & & Haier Smart Home & Manufacturing \\
\hline & & Tencent Holding Limited & Services \\
\hline & & ZTE Corporation & Manufacturing \\
\hline \multirow{3}{*}{3} & \multirow{3}{*}{ Finland } & Nokia Corporation & Manufacturing \\
\hline & & Telefonaktiebolaget LM Ericsson & Services \\
\hline & & Vaisala Oyj (VAIAS.HE) & Manufacturing \\
\hline \multirow{2}{*}{4} & \multirow{2}{*}{ Germany } & Dell Technologies & Manufacturing \\
\hline & & SAP SE & Services \\
\hline \multirow{10}{*}{5} & \multirow{10}{*}{ India } & Accelya & Services \\
\hline & & Mastek & Services \\
\hline & & Birlasoft & Services \\
\hline & & HCL Technologies & Services \\
\hline & & Himachal & Manufacturing \\
\hline & & Infosys & Services \\
\hline & & $\mathrm{L} \& \mathrm{~T}$ & Services \\
\hline & & Mphasis & Services \\
\hline & & Sonata Software & Services \\
\hline & & Sterlite & Manufacturing \\
\hline
\end{tabular}




\begin{tabular}{|c|c|c|c|}
\hline & & Tata Consultancy & Services \\
\hline & & Tech Mahindra & Services \\
\hline & & Wipro & Services \\
\hline & & Zensar & Services \\
\hline & & HEG & Manufacturing \\
\hline & & IFB & Manufacturing \\
\hline & & Voltamp & Manufacturing \\
\hline \multirow{2}{*}{6} & \multirow{2}{*}{ Indonesia } & PT Sarana Menara & Manufacturing \\
\hline & & PT Supreme Cable Manufacturing & Manufacturing \\
\hline \multirow{9}{*}{7} & \multirow{9}{*}{ Japan } & Kanematsu & Services \\
\hline & & Baycurrent & Services \\
\hline & & Keyence Corp & Manufacturing \\
\hline & & Sato Holding & Manufacturing \\
\hline & & Sony Corp & Manufacturing \\
\hline & & Tokyo Electron & Manufacturing \\
\hline & & OMRON Corporation & Manufacturing \\
\hline & & Otsuka Corporation & Services \\
\hline & & NS Solutions Corporation & Services \\
\hline 8 & Netherland & ASM Holding & Manufacturing \\
\hline \multirow{2}{*}{9} & \multirow{2}{*}{ Pakistan } & Avanceaon & Manufacturing \\
\hline & & Hum Network & Services \\
\hline
\end{tabular}




\begin{tabular}{|c|c|c|c|}
\hline & & Netsol & Services \\
\hline & & PTC & Services \\
\hline & & System Limited & Services \\
\hline & & TRG & Manufacturing \\
\hline & & Yandex N.v & Services \\
\hline & & Public Joint Stock Company RBC & Services \\
\hline & & Open Joint Stock Company & Manufacturing \\
\hline & & Levenhuk JSC (LVHK.ME) & Manufacturing \\
\hline & & Car track & Services \\
\hline & & MiX Telematics Limited & Services \\
\hline & & Data tec & Services \\
\hline & & Nasper & Services \\
\hline & & Asia Pacific Sataellite & Manufacturing \\
\hline & & CYMECHS & Manufacturing \\
\hline & & Dongwon System & Manufacturing \\
\hline & & DukSan Neolux & Manufacturing \\
\hline 12 & South Korea & EO Technics & Manufacturing \\
\hline & & Hankook & Services \\
\hline & & KL-Net Corp & Services \\
\hline & & Mico Limited & Manufacturing \\
\hline & & NextEye Co & Manufacturing \\
\hline
\end{tabular}




\begin{tabular}{|c|c|c|c|}
\hline & & Samsung Electronic & Manufacturing \\
\hline & & Signetic Corporation & Manufacturing \\
\hline \multirow{2}{*}{13} & \multirow{2}{*}{ Taiwan } & Taiwan Semiconductor & Manufacturing \\
\hline & & Yageo Corporation & Manufacturing \\
\hline \multirow{11}{*}{14} & \multirow{11}{*}{ USA } & Amadeus & Services \\
\hline & & Accenture & Services \\
\hline & & Cisco Systems & Manufacturing \\
\hline & & Cognizant & Services \\
\hline & & Fujitsu & Services \\
\hline & & Intel Corporation & Manufacturing \\
\hline & & International Business Machine & Services \\
\hline & & Microsoft Corporation & Services \\
\hline & & NIVIDIA & Manufacturing \\
\hline & & ORACLE & Services \\
\hline & & Texas Instruments & Manufacturing \\
\hline
\end{tabular}

\subsection{Trend Analysis}

\subsubsection{Scatter Plot Analysis:}


Plot A (ROA vs Intangible/total assets

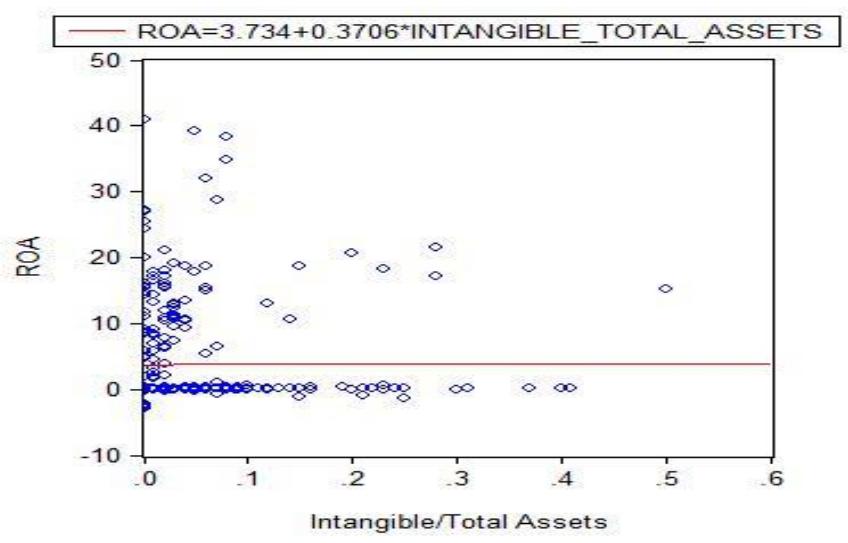

In Plot A, the data points line up very nicely! we can easily draw a horizontal line amongst these dots, and the line would be a good fit to the data. However, the fact that the line would be horizontal means that the input values (that is, Intangibles/Total Assets) are irrelevant to the output values (that is, ROA). So there is a definite trend to the data, and there is an excellent good-fit line for it, but that line only says that the input values are irrelevant. If the inputs are irrelevant, then there can't possibly be a correlation between inputs and outputs.

\section{Plot B (Debt to Equity vs Intangible/total assets}

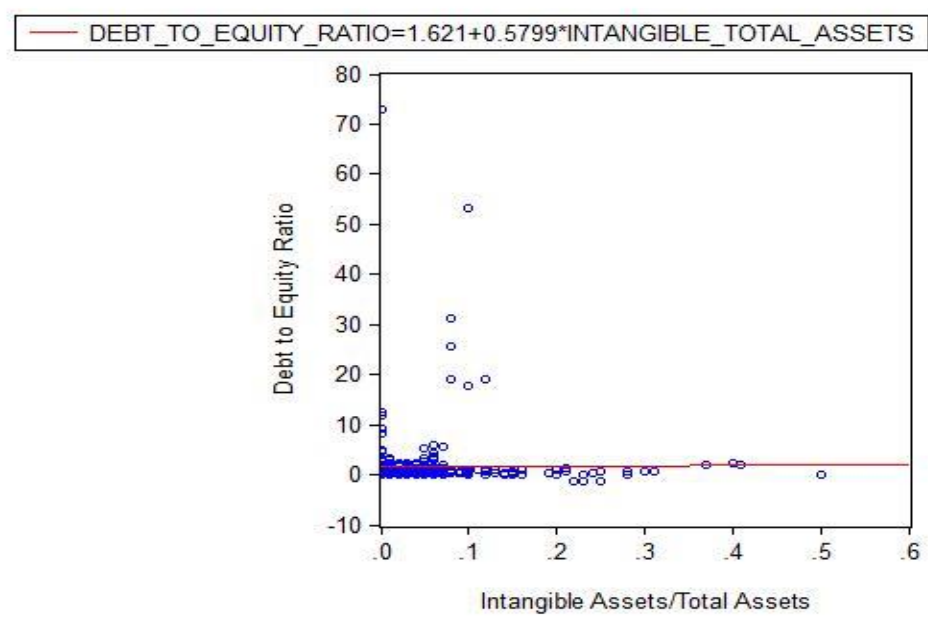

In Plot B shows a bunch of dots, we can draw a horizontal line amongst these dots, and the line would be a good fit for the data but at some extent increasing at the bottom. However, the fact that the line would be horizontal means that the input values (that is, Intangibles/Total Assets) are irrelevant to the output values (that is, Debt to Equity Ratio). If the inputs are irrelevant, then there can't possibly be a correlation between inputs and outputs. 


\section{Plot C (Dividend Payout Ratio vs Intangible/total assets}

\section{DIVIDEND_PAYOUT_RATIO $=0.3599+0.8249 *$ INTANGIBLE_TOTAL_ASSETS}

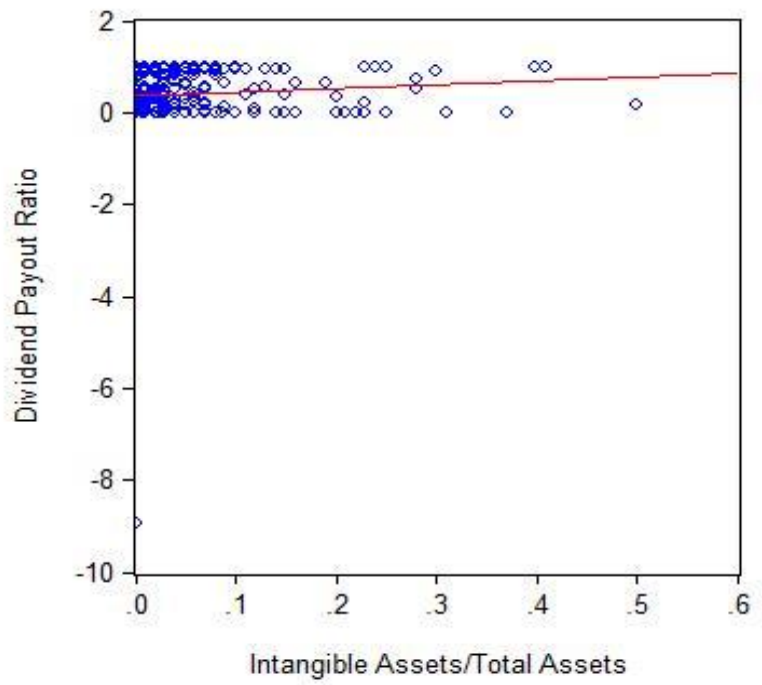

Plot $\mathrm{C}$ shows a bunch of dots, where low $\mathrm{x}$-values that is (Intangible Assets/Total Assets) correspond to low y-values (Dividend Payout Ratio), and high $\mathrm{x}$-values correspond to high $y$-values. It's fairly obvious to me that we could draw a straight line, starting near the left-most dot and angling upwards as I move to the right, amongst the plotted data points, and the line would look like a good match to the points. Such a line would have a positive slope, and the plotted data points would all lie on or very close to that drawn line.

So there does appear to be a strong correlation here and, because the good-fit line drawn amongst these points would have a positive slope, that correlation is positive.

\section{Plot D (Price Earning Ratio vs Intangible/total assets}

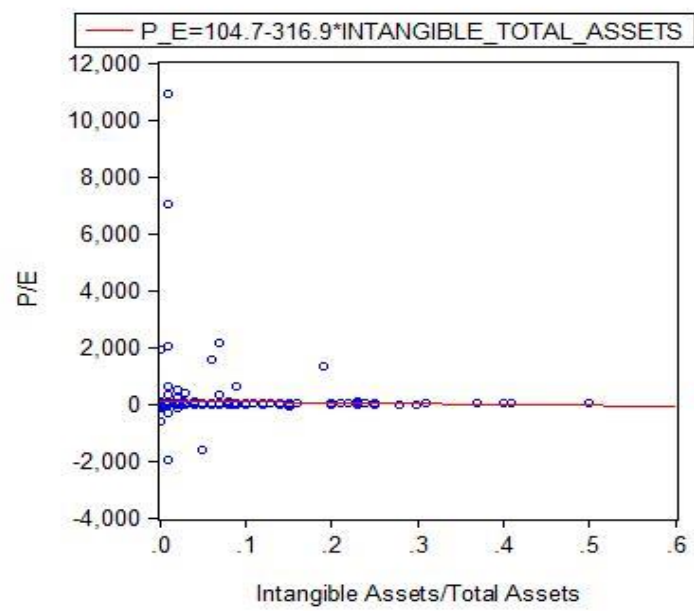




\section{Macrothink}

Plot D shows a bunch of dots, where low $\mathrm{x}$-values (Intangible Assets/Total Assets) correspond to high y-values (P/E), and high x-values correspond to low y-values. It's fairly obvious to me that I could draw a straight line, starting from around the left-most dot and angling downwards as I move to the right, amongst the plotted data points, and the line would look like a good match to the points. Such a line would have a negative slope, and the plotted data points would all lie on or very close to that drawn line.

So there does appear to be a strong correlation here and, because a good-fit line drawn amongst these points would have a negative slope, that correlation is negative.

Country wise time series graph from 2015-2018

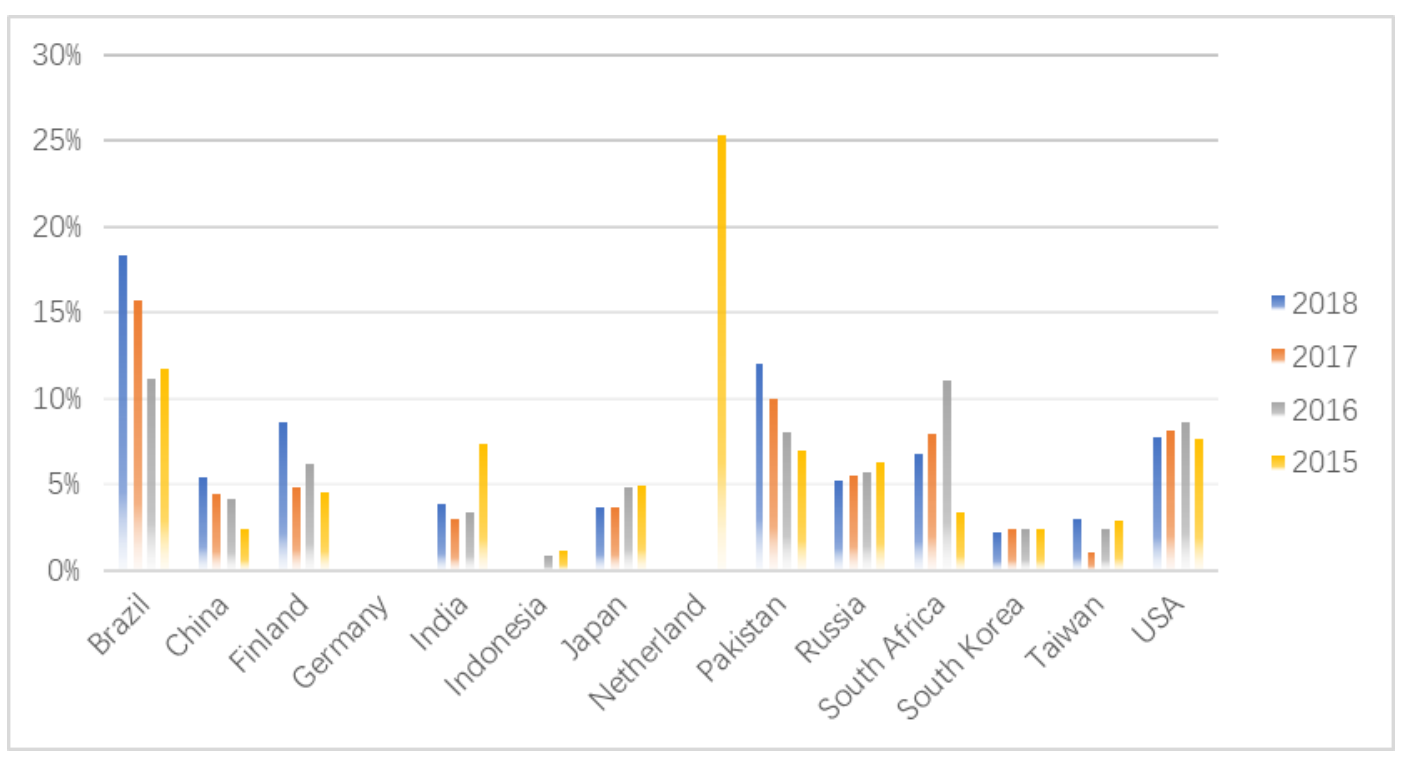

Time series line chart indicates that trends in Brazil, China, Finland, Pakistan, Taiwan, and USA are increasing over a while from 2015 to 2018 and rest of the countries follow the trend of decreasing over a period of time.

\subsection{Research Method}

The study used accounting-based data for intangible assets \& financial indicators of the firm's income statement \& balance sheet or in disclosures of the annual report. To examine the effect of the firm's intangible assets on the firm's performance, firm policy \& firm value we estimate SEM Equation Model through Smart PLS 3.

$\mathrm{IA}=\alpha+\beta 1 \mathrm{ROA}+\beta 2 \mathrm{ATO}+\beta 3 \mathrm{ROE}+\beta 4 \mathrm{ROIC}+\beta 5 \mathrm{PROFITABILITY}+\beta 6 \mathrm{DER}+\beta 7 \mathrm{DPR}+\beta 8 \mathrm{PE}$ $+\beta 9 P B V+\beta 10 P S R+E$ 


\section{I Macrothink}

Table 3. Model Variables

$\begin{array}{lll}\text { Variable Type } & \text { Description }\end{array}$

Intangible Assets

Return on Assets

Asset Turnover Ratio

Return on Equity

Return on Invested Capital

Profitability

Debt to Equity Ratio

Dividend Payout Ratio

Price Earnings Ratio

Price to Book Value

Price to Sales Ratio

\section{Independent Variable}

Dependent Variable

Dependent Variable

Dependent Variable

Dependent Variable

Dependent Variable

Dependent Variable

Dependent Variable

Dependent Variable

Dependent Variable

Dependent Variable
Posted in Financial Statement of Companies

Net Income Divided by Total Assets

Sales Divided by Average Total Assets

Net Income Divided by Total Equity

(Net income - dividend) / (debt + equity).

Net Income Divided by Total Profitability

Total Debt Divided by Total Equity

Dividend per share divided by the Earnings per share

Dividing the market value price per share by the earnings per share

Dividing the market value price per share by the book value per share

Dividing the market value price per share by the sales per share

\section{Results and Data Analysis}

\subsection{Descriptive Statistics (Construct Means and SD)}

This section presents the values for minimum, maximum, mean, and standard deviation for each of the used variables in the research (Table 4)

Table 4. Descriptive Statistics (Country Groups)

\begin{tabular}{|c|c|c|c|c|c|c|c|c|c|c|c|c|c|c|c|c|c|c|c|c|}
\hline & \multicolumn{4}{|c|}{ JAPAN GROUP } & \multicolumn{4}{|c|}{ PAKISTAN GROUP } & \multicolumn{4}{|c|}{ RUSSIA AND CHINA GROUP } & \multicolumn{4}{|c|}{ USA GROUP } & \multicolumn{4}{|c|}{ FINLAND GROUP } \\
\hline & Mean & Min & Max & S.Dev & Mean & Min & Max & S.Dev & Mean & Min & Max & S.Dev & Mean & Min & Max & S.Dev & Mean & Min & Max & S.Dev \\
\hline ROA & 1 & -1 & 15 & 3 & 7 & -3 & 41 & 10 & 4 & -1 & 39 & 4 & 4 & -1 & 29 & 7 & 0 & 0 & 0 & 0 \\
\hline ROE & 2 & -2 & 20 & 5 & 11 & -6 & 103 & 17 & 6 & -1 & 73 & 6 & 6 & -1 & 53 & 12 & 0 & 0 & 0 & 0 \\
\hline ROIC & 2 & -3 & 32 & 6 & 11 & -5 & 80 & 16 & 7 & -17 & 80 & 7 & 6 & 0 & 53 & 12 & 0 & 0 & 0 & 0 \\
\hline ATO & 1 & 0 & 3 & 0 & 56 & 0 & 208 & 62 & 28 & 0 & 208 & 28 & 21 & 0 & 208 & 44 & 0 & 1 & 1 & 0 \\
\hline PROFITABILITY & 5 & 0 & 56 & 12 & 13 & 0 & 434 & 37 & 6 & 0 & 45 & 6 & 49129 & 0 & 2020000 & 293414 & 0 & 0 & 0 & 0 \\
\hline INTANGIBLES & 259070 & 0 & 8350000 & 1 & 7902500 & 0 & 15400000 & 3 & 9083000 & 0 & 15400000 & 9083000 & 12938000 & 0 & 164000000 & 35423400 & 5718040 & 3500 & 15800000 & 5718040 \\
\hline $\begin{array}{l}\text { DEBT TO } \\
\text { EQUITY }\end{array}$ & 1 & 0 & 6 & 1 & 2 & 0 & 53 & 6 & 2 & -1 & 53 & 2 & 2 & 0 & 53 & 6 & 0 & 0 & 2 & 0 \\
\hline $\begin{array}{l}\text { DIVIDEND } \\
\text { PAYOUT }\end{array}$ & 40 & 0 & 99 & 41 & 30 & -896 & 100 & 86 & 45 & 0 & 100 & 45 & 51 & 0 & 100 & 41 & 46 & 0 & 98 & 46 \\
\hline $\begin{array}{l}\text { PRICE } \\
\text { EARNING }\end{array}$ & 224 & -1981 & 10897 & 1436 & 52 & -88 & 2139 & 252 & 55 & -88 & 2139 & 55 & 84 & -88 & 2139 & 330 & 31 & -38 & 90 & 31 \\
\hline P BOOK VALUE & 35 & 0 & 2478 & 264 & 262 & 0 & 10370 & 1380 & 264 & 0 & 10370 & 264 & 271 & 0 & 10370 & 1378 & 10 & 1 & 35 & 10 \\
\hline PSALES & & 0 & 110 & 12 & 18 & 0 & 532 & 61 & 18 & 0 & 532 & & 19 & 0 & 532 & 61 & & 0 & 2 & \\
\hline
\end{tabular}

\subsection{Inter-Construct Correlation}

The table 5 summarizes the inter-construct correlation between different constructs in the study. 


\section{Macrothink

Table 5. Inter-construct Correlation Analysis

\begin{tabular}{|c|c|c|c|c|c|c|c|c|c|c|c|}
\hline & 1 & 2 & 3 & 4 & 5 & 6 & 7 & 8 & 9 & 10 & 11 \\
\hline ROA (1) & 1 & & & & & & & & & & \\
\hline ROE (2) & 0.818 & 1 & & & & & & & & & \\
\hline ROIC (3) & 0.89 & 0.84 & 1 & & & & & & & & \\
\hline ATO (4) & 0.7 & 0.632 & 0.662 & 1 & & & & & & & \\
\hline Profitability (5) & -0.054 & -0.043 & -0.052 & -0.047 & 1 & & & & & & \\
\hline Intangible assets (6) & -0.057 & -0.046 & -0.054 & -0.056 & -0.013 & 1 & & & & & \\
\hline DebttoEquityRatio (7) & -0.091 & -0.071 & -0.094 & -0.077 & 0.007 & -0.016 & 1 & & & & \\
\hline DividendPayoutRatio (8) & -0.014 & 0.014 & -0.021 & -0.067 & 0.063 & 0.085 & -0.114 & 1 & & & \\
\hline PE (9) & -0.049 & -0.042 & -0.052 & -0.058 & -0.009 & 0.31 & -0.022 & 0.067 & 1 & & \\
\hline PBookvalue (10) & -0.062 & -0.052 & -0.063 & -0.068 & -0.011 & -0.016 & 0.019 & -0.052 & -0.024 & 1 & \\
\hline PSales (11) & 0.066 & -0.073 & -0.084 & -0.089 & -0.013 & -0.026 & -0.016 & 0.029 & 0.022 & 0.44 & 1 \\
\hline
\end{tabular}

Structural Equation Model

This section ascertains the proposed relationships in the study. The structural model shows how well the theoretical model predicts the hypothesized paths.

\subsection{Hypotheses Testing (Overall Data)}

H1. Intangible asset has a direct positive impact on the financial performance of the technology firm

H1a: Intangible assets has significant effect on ROE

H1a evaluates the impact of intangible assets on ROE. The hypotheses results show that Assets have a significant negative impact on $\operatorname{ROE}(\beta=-0.045, \mathrm{t}=2.619, \mathrm{p}=0.000)$. This shows that higher intangible assets would lead to lower ROE. Hence, the hypotheses H1a was not supported.

H1b: Intangible assets has significant effect on ROA

$\mathrm{H} 1 \mathrm{~b}$ evaluates the impact of intangible assets on ROA. The hypotheses results show that Assets have a significant negative impact on ROA $(\beta=-0.056, \mathrm{t}=2.570, \mathrm{p}=0.01)$. This shows that higher intangible assets would lead to lower ROA. Hence, the hypotheses H1b was not supported. 


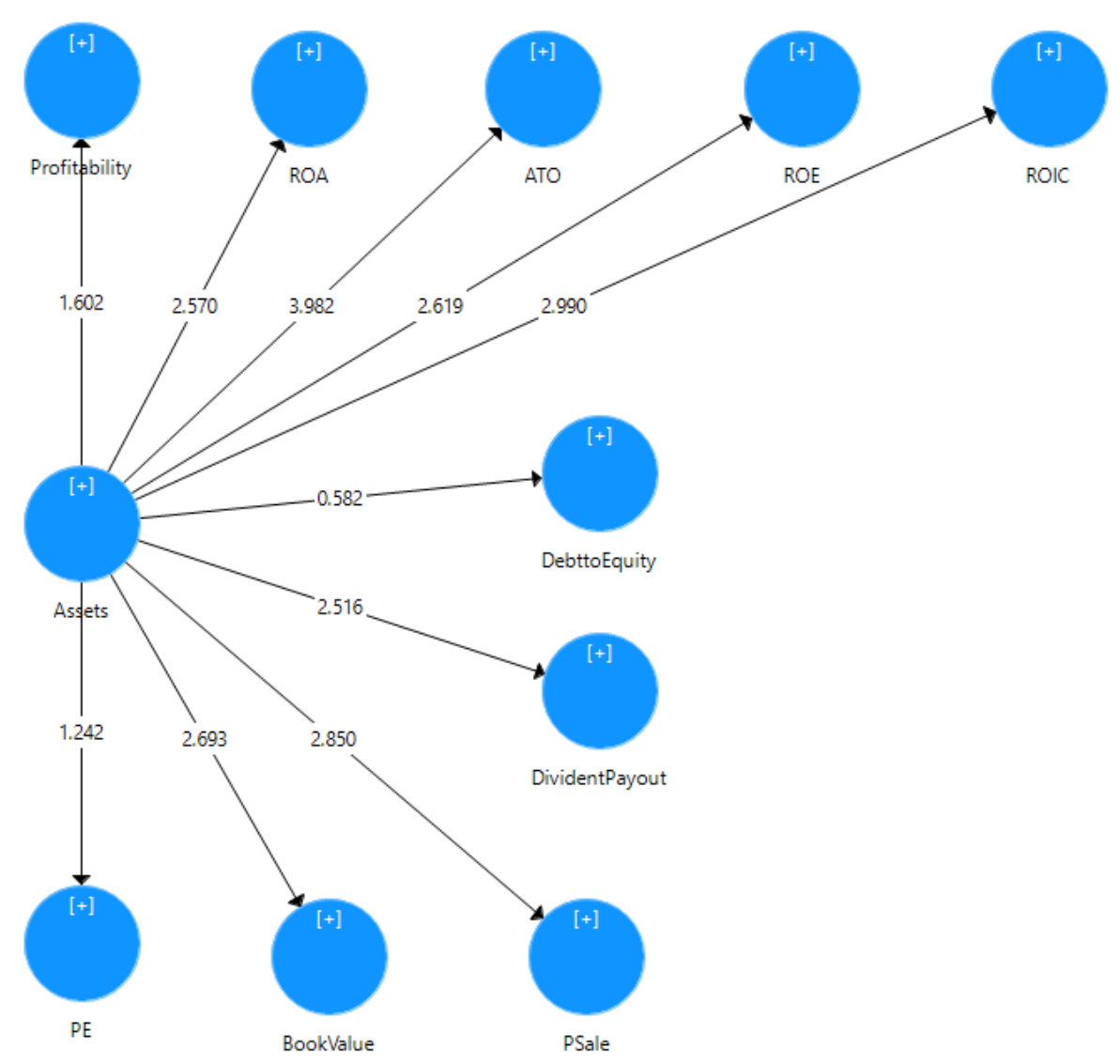

Figure 2. PLS Model

H1c: Intangible assets has significant effect on ROIC

H1c evaluates the impact of intangible assets on ROIC. The hypotheses results show that Assets have a significant negative impact on ROIC $(\beta=-0.053, t=2.990, p=0.003)$. This shows that higher intangible assets would lead to lower ROIC. Hence, the hypotheses H1c was not supported.

H1d: Intangible assets has significant effect on Net Profit Margin

H1d evaluates the impact of intangible assets on Net Profit Margin. The hypotheses results show that Assets have an insignificant impact on Profitability $(\beta=-0.013, t=1.602, p=0.11)$. Hence, the hypotheses H1d was not supported.

H1e: Intangible assets has significant effect ATO. ATO

H1e evaluates the impact of intangible assets on ATO. The hypotheses results show that Assets have a significant negative impact on ATO $(\beta=-0.055, \mathrm{t}=3.982, \mathrm{p}<0.001)$. This shows that higher intangible assets would lead to lower ATO. Hence, the hypotheses H1e was not supported.

H2. Intangible asset has a direct positive impact on the financial policies of technology 


\section{firm.}

H2a: Intangible assets affect debt policy

$\mathrm{H} 2 \mathrm{a}$ evaluates the impact of intangible assets on Debt to Equity. The hypotheses results show that Assets have an insignificant impact on Debt to Equity $(\beta=-0.016, t=0.582, \mathrm{p}=0.561)$. Hence, the hypotheses H2a was not supported.

$\mathrm{H} 2 \mathrm{~b}$ : Intangible assets affect the dividend policy

$\mathrm{H} 2 \mathrm{~b}$ evaluates the impact of intangible assets on Dividend Policy. The hypotheses results show that Assets have a significant positive impact on Dividend Policy $(\beta=0.084, t=2.516$, $\mathrm{p}=0.012$ ). This shows that higher intangible assets would lead to higher dividend payout. Hence, the hypotheses $\mathrm{H} 2 \mathrm{~b}$ was supported.

\section{H3. Intangible asset has a direct positive impact on market value of technology firm}

H3a: Intangible assets has significant effect on P/E

$\mathrm{H} 3 \mathrm{a}$ evaluates the impact of intangible assets on P/E. The hypotheses results show that Assets have an insignificant effect on $\mathrm{P} / \mathrm{E}(\beta=0.304, \mathrm{t}=1.242, \mathrm{p}=0.215)$. Hence, the hypotheses H3a was not supported.

$H 3 b$ : Intangible assets has significant effect on P/Book value

$\mathrm{H} 3 \mathrm{~b}$ evaluates the effect of intangible assets on P/Book Value. The hypotheses results show that Assets have a significant negative effect on $\mathrm{P} /$ Book Value $(\beta=-0.016, \mathrm{t}=2.693, \mathrm{p}=$ 0.007). This shows that higher intangible assets would lead to lower P/Book Value. Hence, the hypotheses $\mathrm{H} 3 \mathrm{~b}$ was not supported.

H3c: Intangible assets has significant effect on P/Sales.

$\mathrm{H} 3 \mathrm{c}$ evaluates the effect of intangible assets on $\mathrm{P} /$ Book Value. The hypotheses results show that Assets have a significant negative effect on $\mathrm{P} / \mathrm{Sale}(\beta=-0.026, \mathrm{t}=2.850, \mathrm{p}=0.005)$. This shows that higher intangible assets would lead to lower P/Sale. Hence, the hypotheses H3c was not supported. 
Table 6. Overall Sample Results

\begin{tabular}{|l|l|l|l|l|}
\hline & Beta & SD & T Statistics & P Values \\
\hline Assets -> ROE & -0.045 & 0.017 & 2.619 & 0.009 \\
\hline Assets -> ROA & -0.056 & 0.022 & 2.57 & 0.01 \\
\hline Assets -> ROIC & -0.053 & 0.018 & 2.99 & 0.003 \\
\hline Assets -> Profitability & -0.013 & 0.008 & 1.602 & 0.11 \\
\hline Assets -> ATO & -0.055 & 0.014 & 3.982 & 0.000 \\
\hline Assets -> DebttoEquity & -0.016 & 0.028 & 0.582 & 0.561 \\
\hline Assets -> DividentPayout & 0.084 & 0.033 & 2.516 & 0.012 \\
\hline Assets -> PE & 0.304 & 0.245 & 1.242 & 0.215 \\
\hline Assets -> BookValue & -0.016 & 0.006 & 2.693 & 0.007 \\
\hline Assets -> PSale & -0.026 & 0.009 & 2.85 & 0.005 \\
\hline
\end{tabular}

\subsection{Country Group Wise Results}

This section after ascertaining the hypothesized relationship in the overall data evaluates the relationships in each of the sample countries. The results are summarized in table 7.

The hypothesis results of country group-wise results show that H1a was supported in Finland group, H1b was also supported in Finland Group, H1c was not supported in any country, H1d was supported in Russia and china group, H1e was not supported in any group, H2a was supported in Pakistan and Russia and China group, H2b supported in Japan and USA Group and $\mathrm{H} 3 \mathrm{a}, \mathrm{H} 3 \mathrm{~b} \mathrm{H} 3 \mathrm{c}$ was not supported in any country group.

\subsection{In Technology Manufacturing Sector}

This section after ascertaining the hypothesized relationship in the overall data evaluates the relationships in each of the sample sectors (Manufacturing and Services). The results are summarized in table 8 .

The hypotheses results of manufacturing sectors show that Assets have a significant negative impact on ROA, ROIC, ATO, Debt to Equity, Price to Book value and Price to Sales, insignificant impact on ROE, Profitability, Dividend Policy.

\subsection{In Technology Services Sector}

The hypotheses results in table 8 of service sectors show that Assets have a significant negative impact on ROE, ROA, ROIC and P/Book Value, insignificant impact on Profitability, ATO, Dividend Policy, P/E and P/Sales, only Debt to equity has a significant positive impact with intangible assets so H2a was supported in Services Sector.

H4: The contribution of intangible assets to a company's financial performance, financial policies \& market value will not be significantly different among the global technological subsector.

To assess whether there are significant differences in the company's financial performance, financial policy, and firm value between the manufacturing and services sector, Multi-Group Analysis (MGA) was performed. The results from MGA revealed that there are differences in 
the significance of the impact of Assets on ROA, ROE, and ROIC $(p<.05)$, however all other differences in significance between the two groups are insignificant. The results are summarized in table 8 .

H5: The contribution of intangible assets to the company's financial performance, financial policy, and market value will not be significantly different among different country's groups.

The study evaluated whether there are significant differences in the company's financial performance, financial policy, and firm value across different countries (Finland, Japan, Pakistan, Russia \& China, and the USA), Multi-Group Analysis (MGA) was performed. The results from MGA revealed that there are differences $(p<.05)$ in the significance of the impact of Assets on the criterion variable between a few countries for instance Asset's impact on ROIC is significantly different between Russia \& China and USA. Results are presented in table 9, a p-value less than .05 indicate a significant difference in the impact of Assets on different outcomes variables between the countries.

Table 7. Country Group Wise Analysis

\begin{tabular}{|c|c|c|c|c|c|c|c|c|c|c|c|c|c|c|c|c|c|c|c|c|}
\hline & \multicolumn{4}{|c|}{ Finland } & \multicolumn{4}{|l|}{ Japan } & \multicolumn{4}{|c|}{ Pakistan } & \multicolumn{4}{|c|}{ Russia and China } & \multicolumn{4}{|l|}{ USA } \\
\hline & Beta & SD & $\mathrm{T}$ & $\mathrm{P}$ & Beta & SD & $\mathrm{T}$ & $\mathrm{P}$ & Beta & SD & $\mathrm{T}$ & $\mathrm{P}$ & Beta & SD & $\mathrm{T}$ & $\mathrm{P}$ & Beta & SD & $\mathrm{T}$ & P \\
\hline Assets -> ROE & 0.202 & 0.099 & 2.044 & 0.041 & -0.073 & 0.023 & 3.151 & 0.002 & -0.173 & 0.047 & 3.715 & 0.000 & -0.133 & 0.081 & 1.645 & 0.101 & -0.129 & 0.053 & 2.424 & 0.016 \\
\hline Assets -> ROA & 0.218 & 0.116 & 1.878 & 0.061 & -0.062 & 0.021 & 3.023 & 0.003 & -0.246 & 0.031 & 8.046 & 0.000 & 0.094 & 0.103 & 0.914 & 0.361 & -0.130 & 0.059 & 2.217 & 0.027 \\
\hline Assets -> ROIC & 0.065 & 0.146 & 0.448 & 0.654 & -0.083 & 0.025 & 3.274 & 0.001 & -0.197 & 0.035 & 5.588 & 0.000 & 0.115 & 0.095 & 1.201 & 0.230 & -0.127 & 0.061 & 2.092 & 0.037 \\
\hline Assets -> Profitability & -0.111 & 0.117 & 0.947 & 0.344 & -0.075 & 0.021 & 3.533 & 0.000 & -0.106 & 0.074 & 1.426 & 0.154 & 0.523 & 0.193 & 2.714 & 0.007 & -0.099 & 0.039 & 2.542 & 0.011 \\
\hline Assets -> ATO & 0.019 & 0.141 & 0.136 & 0.892 & -0.069 & 0.031 & 2.202 & 0.028 & -0.132 & 0.058 & 2.286 & 0.023 & -0.242 & 0.160 & 1.515 & 0.130 & 0.027 & 0.083 & 0.318 & 0.750 \\
\hline Assets -> DebttoEquity & -0.136 & 0.097 & 1.397 & 0.163 & -0.062 & 0.054 & 1.150 & 0.251 & 0.351 & 0.179 & 1.965 & 0.050 & 0.314 & 0.105 & 2.983 & 0.003 & -0.105 & 0.104 & 1.007 & 0.314 \\
\hline Assets -> DividentPayout & 0.088 & 0.199 & 0.443 & 0.658 & 0.265 & 0.057 & 4.685 & 0.000 & -0.055 & 0.089 & 0.615 & 0.539 & 0.127 & 0.146 & 0.867 & 0.386 & 0.188 & 0.060 & 3.115 & 0.002 \\
\hline Assets -> PE & -0.137 & 0.127 & 1.073 & 0.284 & 0.300 & 0.235 & 1.278 & 0.202 & 0.081 & 0.160 & 0.509 & 0.611 & -0.210 & 0.092 & 2.280 & 0.023 & -0.089 & 0.154 & 0.579 & 0.563 \\
\hline Assets -> Book Value & -0.211 & 0.138 & 1.528 & 0.127 & -0.027 & 0.048 & 0.557 & 0.578 & -0.054 & 0.014 & 3.990 & 0.000 & -0.055 & 0.144 & 0.378 & 0.705 & -0.442 & 0.083 & 5.315 & 0.000 \\
\hline Assets -> PSale & -0.311 & 0.093 & 3.366 & 0.001 & -0.056 & 0.056 & 0.993 & 0.321 & -0.031 & 0.063 & 0.489 & 0.625 & -0.214 & 0.093 & 2.306 & 0.022 & -0.478 & 0.125 & 3.828 & 0.000 \\
\hline
\end{tabular}


Table 8. Manufacturing and Services Sector Analysis

\begin{tabular}{|l|l|l|l|l|l|l|l|l|}
\hline & \multicolumn{4}{|l|}{ Manufacturing } & \multicolumn{2}{l|}{ Services } \\
\hline & Beta & SD & T Statistics & P Values & Beta & SD & T Statistics & P Values \\
\hline Assets -> ROE & -0.019 & 0.017 & 1.155 & 0.249 & -0.176 & 0.036 & 4.851 & 0.000 \\
\hline Assets -> ROA & -0.049 & 0.014 & 3.400 & 0.001 & -0.217 & 0.024 & 9.018 & 0.000 \\
\hline Assets -> ROIC & -0.055 & 0.016 & 3.382 & 0.001 & -0.194 & 0.024 & 8.136 & 0.000 \\
\hline Assets -> Profitability & -0.031 & 0.019 & 1.631 & 0.104 & -0.039 & 0.021 & 1.880 & 0.061 \\
\hline Assets -> ATO & -0.056 & 0.015 & 3.774 & 0.000 & -0.085 & 0.058 & 1.465 & 0.144 \\
\hline Assets -> DebttoEquity & -0.038 & 0.014 & 2.698 & 0.007 & 0.324 & 0.137 & 2.366 & 0.018 \\
\hline Assets -> DividentPayout & 0.100 & 0.052 & 1.903 & 0.058 & 0.010 & 0.097 & 0.101 & 0.919 \\
\hline Assets -> PE & 0.301 & 0.238 & 1.265 & 0.206 & 0.039 & 0.091 & 0.432 & 0.666 \\
\hline Assets -> BookValue & -0.090 & 0.020 & 4.427 & 0.000 & -0.060 & 0.012 & 4.951 & 0.000 \\
\hline Assets -> PSale & -0.105 & 0.029 & 3.578 & 0.000 & -0.051 & 0.052 & 0.997 & 0.319 \\
\hline
\end{tabular}

Table 9. Multi-group Analysis - Manufacturing and Services Sector

\begin{tabular}{|l|l|l|}
\hline & Manufacturing - Services & p-Value(Manufacturing vs Services) \\
\hline Assets -> ROE & 0.157 & 0.000 \\
\hline Assets -> ROA & 0.169 & 0.000 \\
\hline Assets -> ROIC & 0.139 & 0.000 \\
\hline Assets -> Profitability & 0.007 & 0.372 \\
\hline Assets -> ATO & 0.029 & 0.308 \\
\hline Assets -> DebttoEquity & 0.361 & 0.995 \\
\hline Assets -> DividentPayout & 0.090 & 0.204 \\
\hline Assets -> PE & 0.262 & 0.118 \\
\hline Assets -> BookValue & 0.030 & 0.890 \\
\hline Assets -> PSale & 0.054 & 0.832 \\
\hline
\end{tabular}

Table 10. Multi-group Analysis-Country Groups

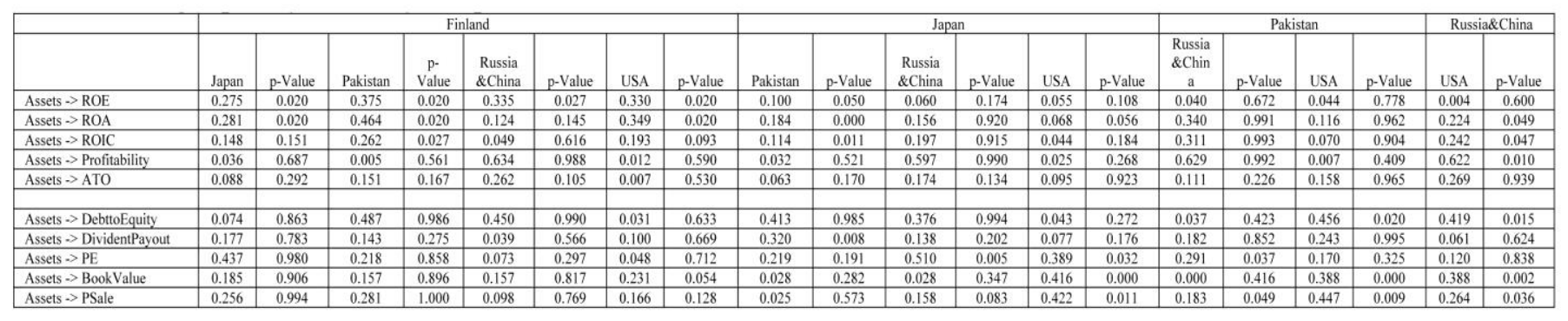

\section{Discussion}

These results support previous research of Haji and Ghazali (2018), Nijun Zhang (2017) Vladimir Dženopoljac, Stevo Janoševic \& Nick Bontis DeGroote (2016) and Gamayuni (2015) found that the higher the intangible assets, the higher the ability of companies to return earnings assets. The higher the intangible assets owned by the company, the higher 
company's ability to generate profits, and investors will appreciate the company (seen from the large market capitalization of companies) that will increase the value of the company. Model 1 of the study shows that intangible assets have a positive impact on the financial performance of the enterprise because out of five proxies, four have the significantly affected by intangibles. Model 2 shows that sub hypothesis dividend policy affects from the intangibles that supported the model also. Model 3 result shows that Price/book value and Price/Sales negatively affected from the intangibles. Model 4 used for sectorial analysis of the technological sector of 80 companies and Multi group Analysis revealed that there difference in the significance on profitability and efficiency, however, all other differences in significance between manufacturing and service are insignificant. The results of the Model 5 revealed that there are significant differences in the company's financial performance, financial policy, and firm value across different countries (Finland, Japan, Pakistan, Russia \& China, and the USA), Multi-Group Analysis (MGA) was performed.

This paper covers the gap by taking comparative analysis among 14 countries and find that results vary country to country and also varies among sectors. This study is will help in find out that the impact of intangibles in technology firm and identify country or sectors means (manufacturing or services) that capitalize intangibles more efficiently.

Intangibles assets are nowadays become the safest investment because it will make your firm stronger and more productive by increasing the market efficiency as well build on profitable channels by showing your goodwill in numbers at the financial position statement of business. By studying from different aspects it is concluded intangible assets is useful resource of the business, it should fairly recorded and disclosed in the balance sheet.

\section{Conclusion}

The current paper supports the impact of intangibles on profitability, efficiency, capital structure, and dividend policy, and market value of technology firms. This paper attempt to cover broader portrait drew from the impact of intangibles by introducing 14 countries financial indicators from 2015 to 2018 . In previous studies, only one country and any specific market aspect covered not global comparative analysis conducted. The main purpose of this study is to find out whether intangibles impact financial indicators of the company or not. For this SEM analysis was conducted that revealed several important points. Firstly in overall data analysis, Intangible assets have a significant negative effect on ROE, ROA, ROIC, ATO, Debt to Equity Ratio, P/book value, P/Sales and insignificant positive impact on profitability, $\mathrm{P} / \mathrm{E}$ and significant positive impact on Dividend Policy. Secondly, country group-wise data revealed that in Finland group intangible assets have significant impact on ROA, ROE and P/Sales, in Japan group intangible assets have significant impact on ROA, ROE, Profitability, ATO, Dividend Policy and P/Book value, In Pakistan group, significant impact on ROE, ROA, ROIC, ATO, Debt to Equity Ratio and P/Book Value, in Russia group significant impact on Profitability, Debt to Equity, P/E and P/Sales ratio and In USA group have a significant impact on ROE, ROA, ROIC, Profitability, Debt to Equity, Dividend Policy, $\mathrm{P} /$ book value, and P/Sales ratio. Third, To assess whether there are significant difference in company's financial performance, financial policy, and firm value between manufacturing 
and services sector, Multi-Group Analysis (MGA) was performed. The results from MGA also revealed that there are difference in the significance of impact of Assets on ROA, ROE, and ROIC ( $\mathrm{p}<.05)$, however all other differences in significance between the two groups are insignificant. Multi group analysis revealed that the significance of impact of Assets on ROA, ROE, and ROIC ( $<<.05)$, however all other differences in significance between the two groups are insignificant. These results support previous research that found that the higher the intangible assets, the higher the ability of companies to return earnings assets. The higher the intangible assets owned by the company, the higher company's ability to generate profits, and investors will appreciate the company (seen from the large market capitalization in companies) that will increase the value of the company.

\subsection{Implication}

In the last few years, the critical importance of intangible assets for enterprises has intensified. As today's corporate asset values shift radically from tangible assets (buildings, inventory, products) to intangible assets (ideas, patents, Intellectual Property or IP), smart companies are using their intangible assets to boost their stock price and create shareholder value (Kahn, 2002). Studies undertaken are mostly limited to a country or region-specific studies. In our opinion, intangible assets are not related to region but to sectors, different sectors have their own peculiar requirement. This research will determine if investment in intangibles is the way out towards improvement in profitability, efficiency, capital structure, and dividend policy, and market value of technology firms as compared to other variables. Our research complements and extends other empirical work that uses financial markets to value IT and other intangible assets. The results direct managers to understand and realize the importance of Intangible Assets and keenly invest in R\&D, technology, software, advertising, CRM and human resources to further augment their performance.

\subsection{Limitations}

The research shows some limitations which, nonetheless, did not affect the results of the study. One limitation is concerned with the lack of information about research and development in regular financial statements or in annual reports or disclosures; further lack was also in accounting information related to intangible assets. The second limitation was linked to the sample of the study; the number of observations was decreased because we excluded many companies that did not provide continuous information over the selected period of the study.

\subsection{Future research}

1. The study uses the metric of market capitalization, which is the most suitable measure because under the analysis it can represent variable intangible assets as a hidden value as a goal. In future studies, other metrics of intangible assets may be used to compare the results.

2. We recommend that public companies use fair value approaches to evaluate the value of assets to improve the quality of earnings and the relevance of financial statements.

3. In the filing of financial statements, some forms of intellectual capital which cannot be 
categorized as intangible assets should be disclosed. It is necessary to standardize the disclosure of intellectual capital as part of intangible assets that are not presented in the balance sheet, to make companies more comparable, so that analysts and investors can take benefit from it.

\section{References}

Abubakar, Modibbo. (2015). Intangible Assets and Value Relevance of Accounting Information of Listed High-Tech Firms in Nigeria. Research Journal of Finance and Accounting, 6, 60-79.

Agrawal, A., \& Knoeber, C. R. (1996). Firm performance and mechanisms to control agency problems between managers and shareholders. Journal of financial and quantitative analysis,31(3), 377-397. https://doi.org/10.2307/2331397

Bchini, B. (2015). Intellectual capital and value creation in the Tunisian manufacturing companies. Procedia economics and finance, 23, 783-791. https://doi.org/10.1016/S2212-5671(15)00443-8

Bubic, J., \& Susak, T. (2015, September). Detecting optimal financial and capital structure: The case of small and medium enterprises (SME) in Republic of Croatia. In 10th International Scientific Conference on Economic and Social Development, Miami.

Carlson, S. J., \& Bathala, C. T. (1997). Ownership differences and firms' income smoothing behavior. Journal of Business Finance \& Accounting, 24(2), 179-196. https://doi.org/10.1111/1468-5957.00101

Choong, K. K. (2008). Intellectual capital: definitions, categorization and reporting models. Journal of intellectual capital. https://doi.org/10.1108/14691930810913186

Connolly, R. A., \& Hirschey, M. (1984). R \& D, Market Structure and Profits: A Value-Based Approach. The Review of Economics and Statistics, 682-686. https://doi.org/10.2307/1935995

Dodd, M. D. (2016). Intangible resource management: social capital theory development for public relations. Journal of Communication Management, Vol. 20(4), 289-311. https://doi.org/10.1108/JCOM-12-2015-0095

Dženopoljac, V., Janoševic, S., \& Bontis, N. (2016). Intellectual capital and financial performance in the Serbian ICT industry. Journal of Intellectual Capital, 17(2), 373-396. https://doi.org/10.1108/JIC-07-2015-0068

Erawati, N. M. A., \& Sudana, I. P. (2005). Intangible Assets. Company Values, and Financial Performance. doi: 10.5897/AJBM2017.8429

Fukao, K., Miyagawa, T., Mukai, K., Shinoda, Y., \& Tonogi, K. (2009). Intangible investment in Japan: Measurement and contribution to economic growth. Review of Income and Wealth, 55(3), 717-736. https://doi.org/10.1111/j.1475-4991.2009.00345.x 
Gamayuni, R. R. (2015). The effect of intangible asset, financial performance and financial policies on the firm value. International journal of scientific \& technology research, 4(1), 202-212.

Gupta, J., Wilson, N., Gregoriou, A., \& Healy, J. (2014). The value of operating cash flow in modelling credit risk for SMEs. Applied Financial Economics, 24(9), 649-660. https://doi.org/10.1080/09603107.2014.896979

Haji, A. A., \& Ghazali, N. A. M. (2018). The role of intangible assets and liabilities in firm performance: empirical evidence. Journal of Applied Accounting Research. https://doi.org/10.1108/JAAR-12-2015-0108

Hejazi, R., Ghanbari, M., \& Alipour, M. (2016). Intellectual, human and structural capital effects on firm performance as measured by Tobin's Q. Knowledge and Process Management, 23(4), 259-273. https://doi.org/10.1002/kpm.1529

Henning, S. L., Lewis, B. L., \& Shaw, W. H. (2000). Valuation of the components of purchased goodwill. Journal of accounting research, 38(2), 375-386. https://doi.org/10.2307/2672938

Holmström, B. (1989). Agency costs and innovation (No. 214). IUI Working Paper. https://doi.org/10.1016/0167-2681(89)90025-5

Iwu-Egwuonwu, D., \& Chibuike, R. (2010). Corporate reputation \& firm performance: Empiricial literature evidence. Ronald Chibuike, Corporate Reputation \& Firm Performance: Empiricial Literature Evidence (August 16, 2010). https://dx.doi.org/10.2139/ssrn.1659595

Jensen, M. C., \& Meckling, W. (1976). H. (1976). Theory of the firm: managerial behavior, agency costs and ownership structure En: Journal of Finance Economics, 3. https://doi.org/10.1016/0304-405X(76)90026-X

Lantz, J. S., \& Sahut, J. M. (2005). R\&D investment and the financial performance of technological firms. International Journal of Business, 10(3), 251.

LEE, H. M., HSU, Y. H., CHEN, T., \& WU, Y. C. (2018). FACTORS THAT AFFECT THE PERCEPTION OF LUXURY BRANDS AFTER M\&A. CLEAR International Journal of Research in Commerce \& Management, 9(1).

Lev, B., \& Gu, F. (2016). The end of accounting and the path forward for investors and managers. John Wiley \& Sons. https://doi.org/10.1002/9781119270041

Lim, S. C., Macias, A. J., \& Moeller, T. (2019). Intangible assets and capital structure. Available at SSRN 2514551.

Lumapow, L. S., \& Tumiwa, R. A. F. (2017). The effect of dividend policy, firm size, and productivity to the firm value. Research Journal of Finance and Accounting, 8(22), 20-24.

Marr, B., \& Schiuma, G. (2001). Measuring and managing intellectual capital and knowledge assets in new economy organisations. Handbook of performance measurement, Gee, London, $369-411$. 
Martins, J., \& Alves, S. (2010). The impact of intangible assets on financial and governance policies: A literature review. Portuguese Journal of Management Studies, 15(1), 87-107.

Mendoza, R., \& Rivera, J. P. R. (2017). The effect of credit risk and capital adequacy on the profitability of rural banks in the Philippines. Annals of the Alexandru Ioan Cuza University-Economics, 64(1), 83-96. https://doi.org/10.1515/aicue-2017-0006

Mortensen, J., Eustace, C., \& Lannoo, K. (1997, March). Intangibles in the European economy. In CEPS workshop on intangibles in the European economy. Brussels.

Noradiva, H., Parastou, A., \& Azlina, A. (2016). The effects of managerial ownership on the relationship between intellectual capital performance and firm value. International Journal of Social Science and Humanity, 6(7), 514. https://doi.org/10.7763/IJSSH.2016.V6.702

Nuryaman, N. (2015). The Influence of Intellectual Capital on The Firm's Value with The Financial Performance as Intervening Variable.Procedia-Social and Behavioral Sciences, 211, 292-298. https://doi.org/10.1016/j.sbspro.2015.11.037

OECD. (2011). OECD MRL calculator: spreadsheet for single data set and spreadsheet for multiple data set, 2 March 2011.

Ozkan, N., Cakan, S., \& Kayacan, M. (2017). Intellectual capital and financial performance: A study of the Turkish Banking Sector. Borsa Istanbul Review, 17(3), 190-198. https://doi.org/10.1016/j.bir.2016.03.001

Peters, R. H., \& Taylor, L. A. (2017). Intangible capital and the investment-q relation. Journal of Financial Economics, 251-272. https://doi.org/10.1016/j.fineco.2016.03.011

Roos, G., \& Roos, J. (1997). Measuring your company's intellectual performance. Long range planning, 30(3), 413-426. https://doi.org/10.1016/S0024-6301(97)90260-0

Sougiannis, T. (1994). The accounting based valuation of corporate R\&D. Accounting review, 44-68.

Sveiby, K. E. (1998). Intellectual capital: Thinking ahead. Australian Cpa, 68, 18-23.

Vodák, J. (2011). The Importance of Intangible Assets for Making the Company's Value. Human Resources Management \& Ergonomics, 5(2), 104-119. https://doi.org/10.11118/actaun201866020431

Yahaya, O. A., \& Lamidi, Y. (2015). Empirical examination of the financial performance of Islamic banking in Nigeria: A case study approach. International Journal of Accounting Research, 42(2437), 1-13. https://doi.org/10.12816/0017347

Zeb, S., \& Rashid, A. (2016). Impact of Financial Health and Capital Structure on Firm's Value, with Moderating Role of Intangible Assets. Global Management Journal for Academic \& Corporate Studies, 6(1), 37. 


\section{Macrothink}

Zhang, L., Pei, D., \& Vasarhelyi, M. A. (2017). Toward a new business reporting model. Journal of Emerging Technologies in Accounting, 14(2), 1-15. https://doi.org/10.2308/jeta-10570

Zhang, N. (2017). Relationship between Intangible Assets and Financial Performance of Listed Telecommunication Firms in China, Base on Empirical Analysis. African Journal of Business Management, 11(24), 751-757.

\section{Copyright Disclaimer}

Copyright for this article is retained by the author(s), with first publication right granted to the journal.

This is open-access article distributed under the terms and conditions of the Creative Commons Attribution license (http://creativecommons.org/license/by/4.0). 